\title{
Meningiomas after radiation-therapy for benign astrocytomas
}

\author{
J. Martínez-Lage*; J. Ros de San Pedro; M. Martínez-Pérez and M. Poza*
}

Servicio Regional de Neurocirugía. Hospital Universitario Virgen de la Arrixaca, Murcia. *Laboratorio de Neurología y Neurocirugía Experimental (NYNE), grupo Omega. Facultad de Medicina. Universidad de Murcia, Campus de Espinardo. Murcia.

\section{Summary}

A 4.5 year-old-girl was submitted to subtotal removal of a benign astrocytoma of the left temporal lobe with basal ganglia extension and given radiotherapy. At age 27 , she was found to harbor a right posterior frontal meningioma that was totally removed. A recurrence of the right convexity meningioma was again excised after a 4-year interval. The authors report this case to illustrate the possibility of the appearance of radiationinduced meningiomas after an interval of 22 years and briefly discuss 16 previous reports on this occurrence in benign astrocytomas.

KEY WORDS: Radiation-induced meningioma. Radiation-induced neoplasms. Benign astrocytoma. Second neoplasms. Radiotherapy complications.

Meningiomas tras radioterapia en astrocitomas benignos

\section{Resumen}

Se presenta el caso de una niña de 4 años y medio que recibió radioterapia local tras la resección casi total de un astrocitoma benigno temporal izquierdo con extensión a ganglios basales. A los 27 años fue operada con extirpación macroscópica total de un meningioma frontal posterior derecho, que recidivó y fue reoperado 4 años más tarde. El propósito de la comunicación es comentar la posibilidad de la aparición de un meningioma radioinducido 22 años después de la radioterapia y revisar brevemente 16 casos similares de meningioma tras la radioterapia en astrocitomas benignos.

PALABRAS CLAVE: Meningioma radioinducido. Tumor radioinducido. Astrocitoma benigno. Segundos tumores. Complicaciones de la radioterapia.

\section{Introduction}

Radiotherapy has been used to treat benign conditions as tinea capitis, arteriovenous malformations, and incompletely resected benign neoplasms, in addition to its generalized use for treating malignant tumors ${ }^{1,6,16}$. Radiation is also being used for producing lesions in functional neurosurgery, as in cases of trigeminal neuralgia, epilepsy, etc. The two main recognized hazards of radiation therapy consist of occlusive vasculopathy and induction of second neoplasms ${ }^{1,10}$. The most frequently reported tumors following $\mathrm{x}$-ray therapy are glioma, sarcoma and meningioma, being the last one the most repeatedly documented in the literature $^{1,6,16}$. To our knowledge, radiation-induced memingiomas have been described in only 16 instances of confirmed, or suspected, benign astrocytoma or glioma $a^{1,2,4,5,7-15,17,18}$. In this report, the authors describe a radiation-induced meningioma appearing 22 years after x-ray therapy of a benign astrocytoma and summarize 16 instantes of this occurrence previously documented in the literature.

Report of the case. A right-handed girl was initially seen at age 4.5-year with symptoms of raised intracranial pressure lasting for 1-month. On examination, the child was conscious, had papilledema, and mild right-side weakness with right Babinski sign. Sensations could not be adequately explored. Plain skull radiographs of the girl showed suture diastasis and an omega shaped sella. Left carotid angiography revealed mass effect on the right temporal lobe.

Ventriculography demonstrated a large lesion that originated at the left temporal lobe displacing the posterior part of the third ventricle. A computerized tomography scan (CT) demonstrated that the neoplasm had hypodense and cystic components, together with a medial portion that stained after the intravenous administration of contrast. In April $20^{\text {th }} 1977$, the child underwent a left temporal craniotomy with nearly total tumor removal, leaving only a small portion adjacent to the thalamus. Histopathological diagnosis was of benign astrocytoma. In view of the incomplete tumor resection, the child was given radiotherapy on the

Recibido: 13-09-04. Aceptado: 18-10-04 

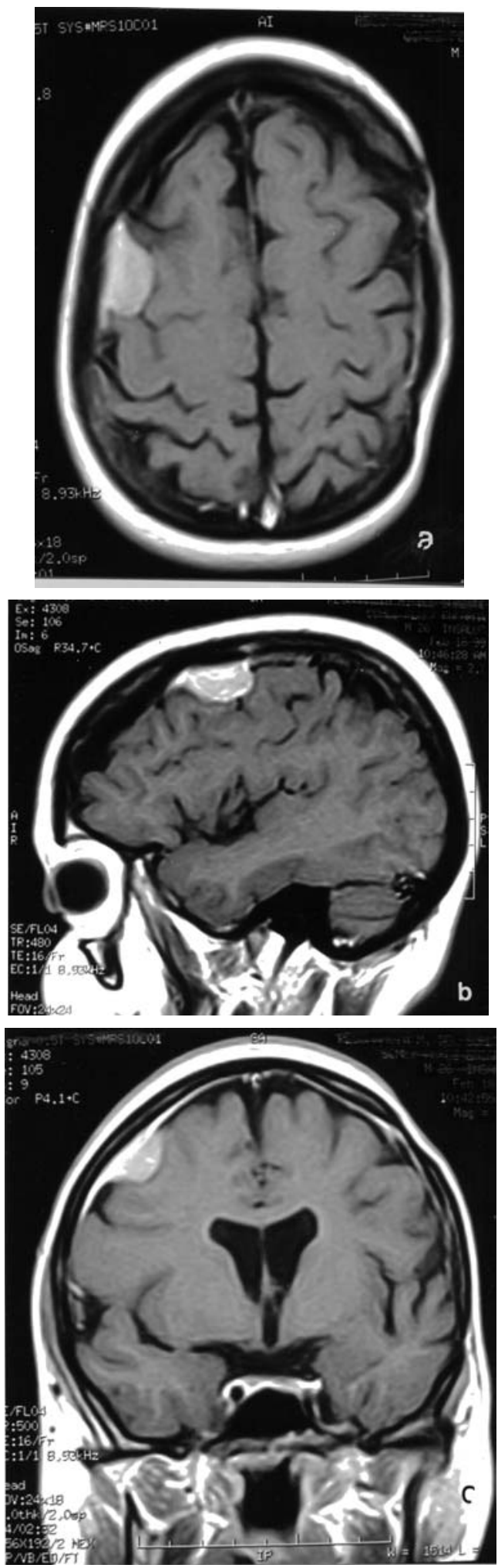

Figura 1. Post-contrast MR of radiation-induced meningioma revealing the tumor with its dural attachment and "dural tail" in (a), axial, (b) sagittal, and (c) coronal views tumoral bed with a total dose of 4.5 Gy. In December 1988, at age 11 , the child presented with seizures and symptoms and signs of increased intracranial pressure. After diagnosic work-up, she was operated on again with apparent total removal of a recurrent benign astrocytoma composed of solid and cystic portions. The girl worsened slightly of a pre-existing right hemiparesis. Although the child now used both hands, she still showed a right hand preference and had no speech involvement.

At age 27, and during a routine follow-up visit, the girl underwent a magnetic resonante (MR) study that showed the appearance of a $2.5 \mathrm{~cm}$ in diameter homogeneous lesion, attached to the dura mater, on the right frontal convexity (Fig. 1 a, b, y c). There was no evidente of recurrence at the site of the initial tumor. On June 2, 1999, the patient underwent an in-block complete removal of the tumor without special difficulties. Histopathological study of the excised lesion showed it was a meningothelial meningioma. She had a normal postoperative recovery.

Four years later, and during a routine follow-up revision, a repeat MR study demonstrated a recurrence of the previously operated meningioma, of similar charactenstics to the preceding one. On May 3, 2004, the girl was again submitted to tumor removal. In this occasion, the craniotomy was enlarged and the tumor plus $1-2 \mathrm{~cm}$ of lesionfree dura was excised ${ }^{7}$. During the procedure, a small vessel traversing the depth of the tumor was coagulated. On awakening of the anesthesia, the girl exhibited aphasia, which cleared up almost completely in a 3-month period. The microscopic study of the recurrence showed it was a meningioma, with a predominant pattem of meningothelial elements and a Ki-67 1abeling index lower than 4\%.

\section{Discussion}

High-dose radiation therapy is currently indicated as adjuvant treatment in the management of primary malignant or secondary tumors of the central nervous system ${ }^{1,6}$. Irradiation has also been used in incompletely resected neoplasms, recurrence, or in cases in which patients are not in a good physical condition for resisting an operative or an anesthetic procedure ${ }^{1,6}$. Radiation therapy has also been used in cases of vascular malformations and in the treatment of functional disorders, as trigeminal neuralgia and epilepsy ${ }^{1,6}$. In the past, tinea capitis in children was treated with low-dose radiation-therapy ${ }^{16}$. Common minor symptoms arising from radiation treathment include nausea, vomiting, dizziness, and loss of appetite. Alopecia is also an untoward effect of radiation therapy that is frequently poorly tolerated by the patients. Some authors have noted the presence of a scalp lesion overlying the site of a radiation-induced meningioma: a sort of "skin marker" signaling the connection with a meningioma ${ }^{3}$. Major effects 
Table

Reported cases of radiation-induced meníngioma after $x$-ray treatment for benign gliomas

\begin{tabular}{|c|c|c|c|c|}
\hline Author (ref) & Age (yrs), sex & Primary diagnosis & Latency (yrs) & Meningioma site \\
\hline Balasubramaniam $^{2}$ & $1.6, \mathrm{~F}$ & thalamic glioma & 11 & convexity, lt temporoparietal \\
\hline Gautier-Smith ${ }^{4}$ & $10, \mathrm{M}$ & cerebellar astro & 15 & parasagittal, rt \\
\hline Ghim et $\mathrm{al}^{5}$ & $1.6, \mathrm{~F}$ & thalamic astro & 13 & convexity, lt parietal \\
\hline \multirow[t]{2}{*}{ Harrison et $\mathrm{al}^{7}$} & $3, \mathrm{~F}$ & It thalamic glioma & 32 & convexity, lt temporal \\
\hline & $13, \mathrm{~F}$ & rt parietal astro & 50 & convexity, rt parietal \\
\hline \multirow[t]{2}{*}{ MacK \& Wilson ${ }^{8}$} & $13, \mathrm{~F}$ & optic glioma & 19 & n.s. \\
\hline & $13, \mathrm{~F}$ & astro & 27 & n.s. \\
\hline Mann et $\mathrm{al}^{9}$ & $3, \mathrm{~F}$ & lt optic glioma & 6 & orbital roof \\
\hline Montanera et al ${ }^{10}$ & $12, \mathrm{~F}$ & suprasellar astro & 20 & convexity, lt tcmporoparietal \\
\hline Nishio et al $^{11}$ & $23, \mathrm{~F}$ & astro & 14 & convexity, lt frontal \\
\hline Norwood et al ${ }^{12}$ & $10, \mathrm{M}$ & lt optic glioma & 25 & convexity, lt temporoparictal \\
\hline Okamoto et al ${ }^{13}$ & $28, \mathrm{M}$ & astro & 6 & falx \\
\hline Reynier et al ${ }^{14}$ & $4, \mathrm{~F}$ & temporal astro & 24 & posterior fossa \\
\hline Rusyniyak et al ${ }^{15}$ & $21, \mathrm{M}$ & lt pons astro & 2.5 & convexity lt temporal \\
\hline Salvatti et al ${ }^{17}$ & $11, \mathrm{~F}$ & astro & 11 & parasagittal, lt frontal \\
\hline Soffer et $\mathrm{al}^{18}$ & $4.5, \mathrm{M}$ & $3^{\text {rd }}$ vent. astro & 12 & falx, lt parietal \\
\hline Present report & $4.5, \mathrm{~F}$ & lt temporal + thalamic astro & 22 & convexity, rt posterior frontal \\
\hline
\end{tabular}

$\mathrm{M}=$ male; $\mathrm{F}=$ female; astro = astrocytoma; $1 \mathrm{t}=$ left $\mathrm{rt}=\mathrm{rt} ; \mathrm{n} . \mathrm{s} .=$ not specified

of x-ray treatments to the brain include vascular occlusion, radiation-necrosis, dementia and the development of secondary tumors ${ }^{1,6,10.16}$.

The true incidence of radiation-induced neoplasms is presently unknown. Most patients with malignant intracranial processes will probably die of their primary disease without having time to develop a second malignancy. Reports of post-radiotherapy neoplasms often consist of cases of meningioma, malignant glioma, and sarcoma, but meningiomas account for the majority of the instances ${ }^{1}$. Several authors have reported the effects of low-dose radiation therapy for treating benign conditions, as happens with the cohort of children treated for tinea capitis ${ }^{16}$. In these instances, the latency period from radiation to development of a meningioma was of approximately 36 years $^{6}$. Al-Mefty et al. ${ }^{1}$ have recently reviewed their experience with 16 cases of radiation-induced meningiomas and report a latency period of 26.5 years. In their extensive literature review, they include meningiomas that developed after $\mathrm{x}$-ray the- rapy indicated for treatment in a multiplicity of tumors, which included all types of gliomas, medulloblastomas, pituitary adenomas, cancer and leukemia cases ${ }^{1}$. These authors have also studied the cytogenetic characteristics of these tumors and found aberrations in chromosomes $1 \mathrm{p}$, $6 \mathrm{q}$, and $22^{1}$.

We reviewed the literature pertaining to radiationinduced meningiomas and collected 16 cases in which the meningioma developed after x-ray treatment for astrocyto-

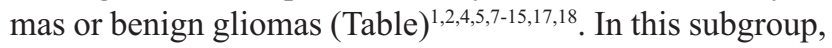
the patients' ages at irradiation ranged from 1.6 to 28 years (mean $10.36 \pm 7.5$ ). Female patients frankly predominated, with a male/female relation of 5:12. This finding suggests that in this group of very young patients, sexual hormones may play an even more significant role in meningioma expansion than in their older counterpart. The interval from irradiation to onset of meningioma signs for these individuals was of $18.2 \pm 11.63$ years (range 2.5 to 50 ). The localization of this group of benign astrocytomas/gliomas 
was randomly distributed as follows: thalamus and third ventricle $(n=4)$, optic nerve-chiasmatic region $(n=4)$, cerebral convexities $(n=3)$, and one case each of brain stem and cerebellar involvement. In four instances, the location of the primary tumor was not specified. The resulting meningiomas predominated at the cerebral convexities $(\mathrm{n}=9)$, or were placed at the falx or parasagittal region $(n=4)$, with one instance each originating at the orbit or in the posterior cranial fossa. Interestingly, most reported cases of meningioma grew on the same side as the primitive tumor or at the midline. In our patient, the meningioma developed in the contralateral hemisphere.

Meningiomas are currently treated by surgery alone, as they usually are grade I tumors, less that there exist malignant or atypical changes within the neoplasm. A higher rate of recurrentes after operation in cases of radiation-induced meningiomas has been noted ${ }^{18}$. The recurrence rate apparently is related not only to the nature of the meningioma proper but also to the capability of performing a total tumoral resection, including tumor-free margins ${ }^{1}$. The use of further $\mathrm{x}$-ray therapy for treating radiation-related meningiomas is disregarded by most authors for obvious reasons. However, stereotactic radiosurgery can be considered when reoperation is disregarded ${ }^{11}$.

\section{Conclusions}

We reviewed 16 instantes of previously reported meningioma following $\mathrm{x}$-ray therapy for treatment of benign gliomas. We have added a new example of this association occurring 22 years after irradiation of a benign astrocytoma. Our results agree with those of other authors: meningiomas after radiotherapy occur mainly in children, they tend to appear at the vault, rarely they are multiple, the majority of them are benign, and most of them are amenable of total resection ${ }^{5}$. A wide bony and dural margin is highly recommended at surgical excision, to prevent recurrences ${ }^{7}$.

\section{Acknowledgments}

The authors greatly appreciate the expertise of $\mathrm{Mr}$. Saturnino Espin, Hospital 's photographer, for preparing the illustrations.

\section{References}

1. Al-Mefty, O., Topsakal, C., Pravdenkova, S., Sawyer, J.R., Harrison, M.: Radiation induced meningiomas; clinical, pathological, cytokinetic, and cytogenetic characteristics. J Neurosurg 2004; 100: 1002-1013.

2. Balasubramaniam, C., Armstrong, D., Cheek, W., Lau- rent, J.: Postradiation meningioma in a child. Pediatr Neurosci 1988; 14: 319-323.

3. García Santos, J.M., Climent, V.: A scalp lesion over an extracerebral mass: a sign of radiation-induced meningioma. Neuroradiology 1992; 34: 428-429.

4. Gautier-Smith, P,C.: Parasagittal and falx meningiomas. London, Butterworth, 1970, pp 280 (cited in 1)

5. Ghim, T.T., Seo, J.J., O'Brien, M., Meacham, L., Crocker, I., Krawiecki, N.: Childhood intracranial meningiomas after high-dose irradiation. Cancer 1993; 71: 4091-4095.

6. Gold, D.G., Neglia, J.P., Potish, R.A.: Second neoplasms following megavoltage radiation for pediatric tumors. Cancer 2004; 100: 212-213.

7. Harrison, M.J., Wolfe, D.E., Lau, T.S., Mitnik, R.J., Sachdev, V.P.: Radiation-induced meningiomas: experience of the Mount Sinai Hospital and review of the literature. J Neurosurg 1991; 175: 564-574.

8. Mack, E.E., Wilson, C.B.: Meningiomas induced by high-dose cranial radiation. J Neurosurg 1993; 79: 28-31.

9. Mann, I., Yates, P.C., Ainslie, P.C.: Unusual case of double primary orbital tumor. Br J Ophthalmol 1953; 37: 758762 (cited in ref. 1).

10. Montanera, W., Chui, M., Hudson, A.: Meningioma and occlusive vasculopathy: coexisting complicatons of past extracranial radiation. Surg Neurol 1985; 24: 35-39.

11. Nishio, S., Morioka, T., Inamura, T., Takeshita, I., Fukui, M., Sasaki, M., et al.: Radiation-induced brain tumors: potential late complications of radiation therapy for brain tumours. Acta Neurochir (Wien) 1998; 140: 763770 .

12. Norwood, W., Kelly, D.L. Jr, Davis, C.H. Jr, Alexander, E. Jr.: Irradiation-induced mesodermal tumors of the central nervous system: report of two meningiomas following X-ray treatment for gliomas. Surg Neurol 1974; 2: 161164.

13. Okamoto, S., Handa, H., Yamashita, J., Tokuriki, Y., Abe, M.: Post-irradiation brain tumors. Neurol Med Chir (Tokyo) 1985; 25: 528-533 (cited in ref. 1)

14. Reynier, Y., Guillermain, P., Jazzar, A., Vigoroux, R.P.: Méningiomes radio-induit. Neurochirurgie 1986; 32: 135139.

15. Rusyniak, W.G., Marchese, M.J., Nelson, C.N.: Benign meningioma with a short latency period after irradiation. Surg Neurol 1992; 38: 261-264.

16. Sadetzki, S., Flint-Ritcher, P., Ben-Tal, T., Nass, D.: Radiation-induced meningioma: a descriptive study of 253 cases. J Neurosurg 2002; 97; 1078-1082.

17. Salvati, M., Cervone, L., Puzzili, F., Bristot, R., Delfini, R., Gagliardi, F.M.: High-dose radiation-induced meningiomas. Surg Neurol 1997; 47: 435-442.

18. Soffer, D., Pittaluga, S., Feiner, M., Beller, A.: Intracranial meningiomas following low-dose irradiation to the head. J Neurosurg 1983; 59:1048-1053. 
Martínez-Lage, J.; Ros de San Pedro, J.; Martínez-Pérez, M.; Poza, M.: Meningiomas after radiation-therapy for benign astrocytomas. Neurocirugía 2005; 16: 266-270.

Comentario al trabajo: Meningiomas after radiationtherapy for benign astrocytomas de Martínez-Lage y cols.

Martínez-Lage y cols. nos presentan un caso clínico de una paciente que, habiendo sido sometida a radioterapia tras una resección subtotal por un astrocitoma grado II, presenta en la convexidad del hemisferio contralateral, 22 años más tarde, un meningioma meningotelial. Asimismo revisan la casuística publicada de este tipo de tumores radio-inducidos cuando el tratamiento era aplicado en astrocitomas de bajo grado. Reconocen en la discusión del caso los principales aspectos que suelen analizarse, como la dosis de radiación administrada, el intervalo o periodo de latencia, la predominancia del sexo femenino y la localización del $2^{\circ}$ tumor en relación con la topografía del campo sometido a radiación, por destacar algunos. Señalan, como se viene apuntando desde principios de la década de los años noventa, cuáles son las características genéticas que este
Correspondencia postal: Juan F. Martínez-Lage Servicio Regional de Neurocirugia. Hospital Universitario Virgen de la Arrixaca E-30120 Murcia. subgrupo de meningiomas pudieran presentar $\mathrm{y}$, aunque no existe un patrón de características únicas, parece que suele tratarse con mayor frecuencia de pacientes del sexo femenino, que fueron sometidas a tratamiento radioterápico en la infancia, con periodos de latencia superiores a los 20 años, topografía ipsilateral a la lesión primera y con mayor predominancia en la convexidad cerebral, que recidivan tras su extirpación quirúrgica y presentan características de atipia o agresividad biológica en mayor porcentaje que los meningiomas no radio-inducidos. En estos últimos hay una asociación con aberraciones citogenéticas del cromosoma 22, mientras que en los meningiomas radio-inducidos se presentan con mayor frecuencia las alteraciones del 1 p. Es posible que esta vía en la oncogénesis permita en el futuro caracterizarlos de forma fidedigna. 